\title{
Orígenes y expresiones de la religiosidad en México. Cultos cristológicos, veneraciones marianas y heterodoxia devocional
}

Guadalupe Salazar Hernández

Doctorado en Historia

Centro de Investigación y Estudios Superiores en

Antropología Social, unidad Peninsular, México

guadalupesalazarh@gmail.com

María Teresa Jarquín Ortega y Gerardo González Reyes (coords.), Orígenes y expresiones de la religiosidad en México. Cultos cristológicos, veneraciones marianas y heterodoxia devocional, Estado de México, El Colegio Mexiquense, 2020, 382 pp., ISBN: 978-6078509-59-1.

La evangelización en Nueva España creó en un principio tensión y se buscó una aculturación entre la religión prehispánica y la católica. Con el tiempo se fueron difuminando las religiones hasta volverse una sola. La religión se utilizó como un espacio donde se realizaron negociaciones, relaciones de poder, organización de la vida cotidiana y demostraciones y expresiones de la religiosidad y fe entre otras muchas. En el libro Orígenes y expresiones de la religiosidad en México. Cultos cristológicos, veneraciones marianas y heterodoxia devocional, publicado por El Colegio Mexiquense en 2020, los coordinadores María Teresa Jarquín Ortega y Gerardo González Reyes junto con otros académicos analizan en distintos periodos de México la religiosidad de la sociedad.

El título muestra de forma general lo que tratan los artículos; la religiosidad en México desde los orígenes, pero también sus diferentes expresiones a través de la historia del país. El subtítulo especifica que serán artículos sobre el culto a distintas imágenes cristológicas, veneraciones a advocaciones marianas y heterodoxia devocional. Desde el principio el libro nos permite esperar una amplia y variada lectura acerca de la (c) (i) (9) Internacional

Secuencia. Reseñas, 2021

http://secuencia.mora.edu.mx

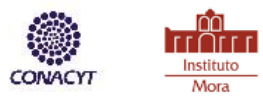


religiosidad a través de distintos estudios de caso, en el centro del país y en distintas épocas. El libro muestra cómo México ha tenido distintas transformaciones en su religiosidad. Aparte de ser demostraciones de fe, también ha servido para poner orden en la sociedad, mantener el respeto, aumentar ingresos y tener prestigio, entre otros muchos aspectos que en cada capítulo demuestran los autores.

Orígenes y expresiones... contiene una introducción y su contenido se divide en tres secciones. La primera son los estudios sobre los cultos cristológicos que incluye tres artículos. La segunda parte, titulada Veneraciones Marianas, está constituida por cinco artículos y la ultima es la Heterodoxia Devocional, con seis artículos.

El primer texto de Gilberto León Vega, titulado "Creación cultural indígena en momentos de idoloclastia hispana. Trasfondo etnohistórico de la escultura del Señor del Calvario en Colhuacan", el cual busca estudiar cómo los indígenas y los religiosos intentaron adaptar costumbres de ambos para la religión católica durante la evangelización. El artículo muestra cómo los indios buscaron esconder las reliquias prehispánicas en las nuevas imágenes católicas, como la del Señor del Calvario en Colhuacan. El autor utiliza la información sobre las reliquias, el peso y material con que se realizó la imagen citada para demostrar que en realidad es un relicario. Asimismo, los religiosos utilizaron el ejemplo de la muerte de Moctezuma en el códice Florentino para explicar la muerte de Jesús. Este estudio de caso es ejemplo de la aculturación en Nueva España. El autor habla de idoloclastia, sin definir el término por lo que es difícil de entender.

El segundo artículo se titula "Un ejemplo de religiosidad barroca, el culto al Cristo de Chalma, siglo XVII” escrito por Gerardo González, Magdalena Pacheco y Rosa María Camacho. Los autores desarrollan en su trabajo el surgimiento de la devoción del Cristo de Chalma, la construcción del mito y sus milagros. A través del estudio de la zona de influencia de la imagen, se demuestra que la tradición y la religiosidad son importantes para generar una identidad local. En el título se utiliza el término religiosidad barroca, sin embargo, no se define qué es la religiosidad y menos qué es lo barroco en el siglo XVII.

"Imagen fiesta y devoción en Atlacomulco. La veneración al Señor del Huerto, siglo XIX” fue escrito por Antonio de Jesús Enríquez Sánchez. El artículo trata de la advocación 
del Señor del Huerto, las expresiones devocionales y las prácticas festivas a través del estudio de los exvotos y milagros del siglo XIX.

Los tres casos muestran la importancia del mito en la construcción de la devoción cristológica y están dedicados al estudio de municipios del Estado de Mèxico.

La segunda parte del libro se ocupa de la veneración mariana. Incluye los escritos de Erika González, "Espacios sagrados de devoción, las capillas a la virgen de Loreto en el Bajío novohispano"; "Celebración y procesión. La cofradía de Nuestra Señora de la Guía y su fiesta titular (1690-1700)" de Yasir Armando Huerta Sánchez; "Mayordomos y bienhechores. La virgen de San Juan de los Lagos y las zonas mineras de Guanajuato, Zacatecas y Real de Bolaños en el siglo XVIII" escrito por Omar López Padilla; "El culto a la virgen de los agraristas: la invención de una tradición” por Francisco Javier Velázquez Fernández y por último "Devoción y prodigios de Nuestra Señora de los Ángeles de la Asunción de Tecaxic durante la época novohispana” por María Teresa Jarquín Ortega.

Cada artículo es un estudio de caso de la imagen de la virgen María en alguna de sus advocaciones en el centro del país. Por medio de la devoción mariana los autores muestran cómo a través del tiempo se ha utilizado la figura de María para distintos fines, no sólo para fomento de la fe católica. Los cinco artículos tienen en común que inician explicando la forma en que la advocación llegó a determinado lugar: por carreta, se encontró en el cerro, posterior a un accidente o la imagen se desempolvó y se volvió conocida. Después de esta hierofanía, se difundieron los milagros, las hazañas y obtuvieron un patrocinador. Algunos de estos elementos permitieron que su fama transciendiera lo local.

Cada uno de los estudios muestra cómo se difundió la fama de la imagen, quiénes patrocinaron la construcción de capillas y las fiestas. Los autores explican su origen e iconografía, así como la expresión de su culto por parte de la población. Para reconstruir esto, hicieron trabajo de campo, usaron el calendario litúrgico y la documentación de archivo sobre mayordomías y cofradías lo que ayudó para explicar al lector cómo funciona la religiosidad mariana en distintos contextos en el centro de país.

La última parte del libro titulada Heterodoxia Devocional está conformada por seis artículos. El primero, de Jesús Alfaro Cruz, "Velos tenues entre dos tribunales novohispanos (Valle de Antequera, 1611-1612)"; estudia cómo el tribunal "fue muy 
cauteloso para argumentar en favor de la legitimidad de la imagen" (p. 242). En la misma línea el texto "Los rosarios del padre José de Lezamis (1684-1750) cura del Sagrario de México”, de Rocío Silva Herrera, muestra cómo en 1749, el Tribunal del Santo Oficio de la Inquisición fue muy cuidadoso en castigar o prohibir un libro que se utilizaba para demostrar la religiosidad de la población.

El artículo "Devociones al oriente del valle de Toluca: Ocoyoacac, Capulhuac y Xalatlaco vistos a través de la visita pastoral de Francisco Aguiar y Seixas", escrito por Edwin Saúl Reza Díaz, busca mostrar que a través de las visitas pastorales el obispo supervisaba las formas de expresión de la población por medio de las fiestas de las advocaciones y la creación y permisos de las cofradías. En el texto "Misma celebración en distintos lugares: diferentes mensajes. Festejos por la canonización de Juan de la Cruz, Puebla de los Ángeles”, de Jessica Ramírez, la autora analiza los festejos de canonización en Puebla, comparándolos con los de la ciudad de México. Ambos artículos estudian los festejos y las procesiones, mostrando la religiosidad de los creyentes y cómo la religión es una parte fundamental de la vida cotidiana.

Los últimos artículos son “"Escándalos” constantes: la reglamentación de la procesión de Corpus Christi en la ciudad de México (siglo XVIII)" de Karen Ivett Mejía y “¿Una feligresía renovada? Congregaciones del Santísimo Sacramento y Escuelas de Cristo en la ciudad de México, siglo XVIII”, escrito por Carolina Yeveth Aguilar. El primero revela la influencia y poder que tuvo la Iglesia para multar y organizar la vida cotidiana de la población. El segundo artículo se centra en demostrar cómo se transformaron las prácticas religiosas de la ciudad de México entre 1750 y 1800 . En ese contexto se utilizaron dos nuevas formas de organización, pues se pasó de las cofradías a las Congregaciones y Escuelas de Cristo. Ambos textos permiten comprender la influencia que tuvo la Iglesia en la vida cotidiana y como ésta se transformó con la sociedad al paso de los años.

En suma, los artículos reunidos aquí nos revelan advocaciones católicas que han sido importantes en la historia de nuestro país. Sería deseable que los conceptos usados fueran claramente definidos para un mejor entendimiento del tema por parte del lector. 
Finalmente, Orígenes y expresiones de la religiosidad en México. Cultos cristológicos, veneraciones marianas y heterodoxia devocional nos da pauta para nuevos estudios a futuro sobre la religión y la religiosidad. 